Article

\title{
Exploration for the Salinity Tolerance-Related Genes from Xero-Halophyte Atriplex canescens Exploiting Yeast Functional Screening System
}

\author{
Gang Yu ${ }^{1}{ }^{\mathbb{D}}$, Jingtao $\mathrm{Li}^{1}{ }^{1}$, Xinhua Sun ${ }^{1}$, Yanzhi Liu ${ }^{1}$, Xueliang Wang ${ }^{1}$, Hao Zhang ${ }^{2, *}$ \\ and Hongyu Pan ${ }^{1, *}$ \\ 1 College of Plant Sciences, Jilin University, Changchun 130062, China; chrisyu_gang@hotmail.com (G.Y.); \\ lijingtao789@126.com (J.L.); xinhua-sun@hotmail.com (X.S.); liuyz8209@mails.jlu.edu.cn (Y.L.); \\ mewxl@163.com (X.W.) \\ 2 College of Resource and Environment, Jilin Agricultural University, Changchun 130062, China \\ * $\quad$ Correspondence: haozhang100@163.com (H.Z.); panhongyu@jlu.edu.cn (H.P.); Tel.: +86-431-8783-5659 (H.P.)
}

Received: 11 October 2017; Accepted: 15 November 2017; Published: 17 November 2017

\begin{abstract}
Plant productivity is limited by salinity stress, both in natural and agricultural systems. Identification of salt stress-related genes from halophyte can provide insights into mechanisms of salt stress tolerance in plants. Atriplex canescens is a xero-halophyte that exhibits optimum growth in the presence of $400 \mathrm{mM} \mathrm{NaCl}$. A cDNA library derived from highly salt-treated A. canescens plants was constructed based on a yeast expression system. A total of 53 transgenic yeast clones expressing enhanced salt tolerance were selected from $10^{5}$ transformants. Their plasmids were sequenced and the gene characteristics were annotated using a BLASTX search. Retransformation of yeast cells with the selected plasmids conferred salt tolerance to the resulting transformants. The expression patterns of 28 of these stress-related genes were further investigated in A. canescens leaves by quantitative reverse transcription-PCR. In this study, we provided a rapid and robust assay system for large-scale screening of genes for varied abiotic stress tolerance with high efficiency in A. canescens.
\end{abstract}

Keywords: Atriplex canescens; salinity tolerance; yeast expression; halophyte; Gene Othology analysis

\section{Introduction}

The world's population is on track to grow from 7 to 9 billion in the next 50 years [1]. Securing the reliable production of staple crops to feed these people is the primary task of governments world-wide and is one of the most important concerns for state security. Abiotic stresses (such as drought, salinity and extreme temperature) negatively impact crop growth and productivity. High soil-salt concentrations not only impair the ability of plants to take up enough water for growth and development, but large amounts of $\mathrm{Na}^{+}$and $\mathrm{Cl}^{-}$uptake negatively impacts growth by impairing metabolic processes and decreasing photosynthetic efficiency [2]. In the face of salt stress, plants use coordinated strategies to combat salt stress which associates with Reactive oxygen species (ROS) generation and detoxification pathways, signal transduction, osmo-regulation or ion homeostasis by osmoprotectants, and regulated expression of salt responsive genes and transcription factors [3]. Exogenous application of chemicals including compatible solutes and hormones, like glycine betaine, glutathione, polyamines, nitric oxide (NO), brassinosteroids (BRs) and salicylic acid (SA), were also reported as an effective approach to increase the salt resistance in certain plant species [4].

The identification of elements of salt stress resistance is still a major topic in plant breeding and genetic engineering. Currently, plant abiotic stress research is mainly focused on herbaceous plants, while abiotic stress resistance determinants in woody halophytes are as yet rarely investigated. Notably, Casuarina glauca, an actinorhizal plant with N2-fixing bacteria of the genus Frankia, is a good model 
to investigate relationship among plant, abiotic stress and symbiotic microbes and its salt-resistant characteristics have been extensively characterized at the physiological level, such as photosynthesis, nitrogen metabolism, membrane integrity and antioxidative system and metabolome [5-8]. Halophytes have been considered to be an elite resistance gene resource, and research has become focused on isolation and functional characterization of their genes $[9,10]$. Whole genome sequence information of laboratory model plants including Arabidopsis thaliana, and Thellungiella salsuginea has made possible comparative analysis of a glycophyte (A. thaliana) and a haplophyte (T. salsuginea) [11]. Such comparative genomics and experimental analyses have demonstrated that gene families categorized to cation transport, abscisic acid signaling, and wax production in T. salsuginea might contribute to its success in stressful environments [11]. Another study focusing on physiological and proteomic analyses of salt stress responsive genes in the halophyte Halogeton glomeratus proposed that photosynthesis, energy production, ion homeostasis and oxygen radical scavenging enzymes are involved in maintaining homeostasis under conditions of salt stress [9]. Transcriptomics and subsequent microarray analysis identified genes involving in osmotic and ionic homeostasis, redox equilibrium and signal transduction during salt treatment of another halophyte Atriplex centralasiatica [12]. Advances in genome sequencing is driving a revolution in genomics, transcriptomics and proteomics analysis in the investigation of molecular and biochemical mechanisms that underpin biological functions and is providing strategies for crop improvement [13]. But the raw data provided by the "omics" approaches does not identify precise controlling factors in many of these biological processes.

The elite halophyte Atriplex canescens (four-wing saltbush), a member of the Chenopodiaceae, is indigenous in arid and semi-arid areas of western North America. A. canescens exhibits tolerance to salinity, drought, heavy metals and low temperature and the plant has been employed in phytoremediation of saline-alkali and heavy-metal contaminated soils [14]. Therefore, the plant is a source of genes that could be employed in the genetic manipulation of crops for improvements in salt, drought and low temperature stress [14]. Yeast expression systems have been extensively used for protein functional characterization and protein production, combining advantages in rapid growth and facile genetic manipulation with the relevance of a eukaryotic expression system, such as capacity for post-translational modifications [15]. Some recent studies demonstrated that the yeast expression system is suitable to isolate genes responsible for salt-, drought-, and high temperature-resistance in Jatropha curcas, tomatos and Salicornia europaea, respectively [16-19]. Since little is known about molecular determinants and mechanisms for adaption to salt stress in woody halophyte $A$. canescens, we describe a yeast expression and screening system to rapidly and efficiently isolate salt-responsive genes from that source.

\section{Results}

\subsection{Generation of the Yeast Expression cDNA Library}

A yeast expression library was constructed using the SuperScript full-length Library Construction Kit II, following manufacturer's instructions (Figure 1). Approximately, $1.76 \times 10^{6}$ colony-forming units (CFU) of $E$. coli transformants harboring A. canescens $\mathrm{CDNA}$ inserts by $\mathrm{BP}$ reaction were generated in pDONR222 with a recombinant rate of $91 \%$. And the primary cDNA library was transferred to a yeast expressional destination vector PYES-DEST52 by LR reaction with a recombinant rate about $95 \%$ [20]. The size of cDNA inserts ranged from 0.6 to $2 \mathrm{~kb}$ and the average inserted fragment is sized above $1 \mathrm{~kb}$ (Table 1$)$. 


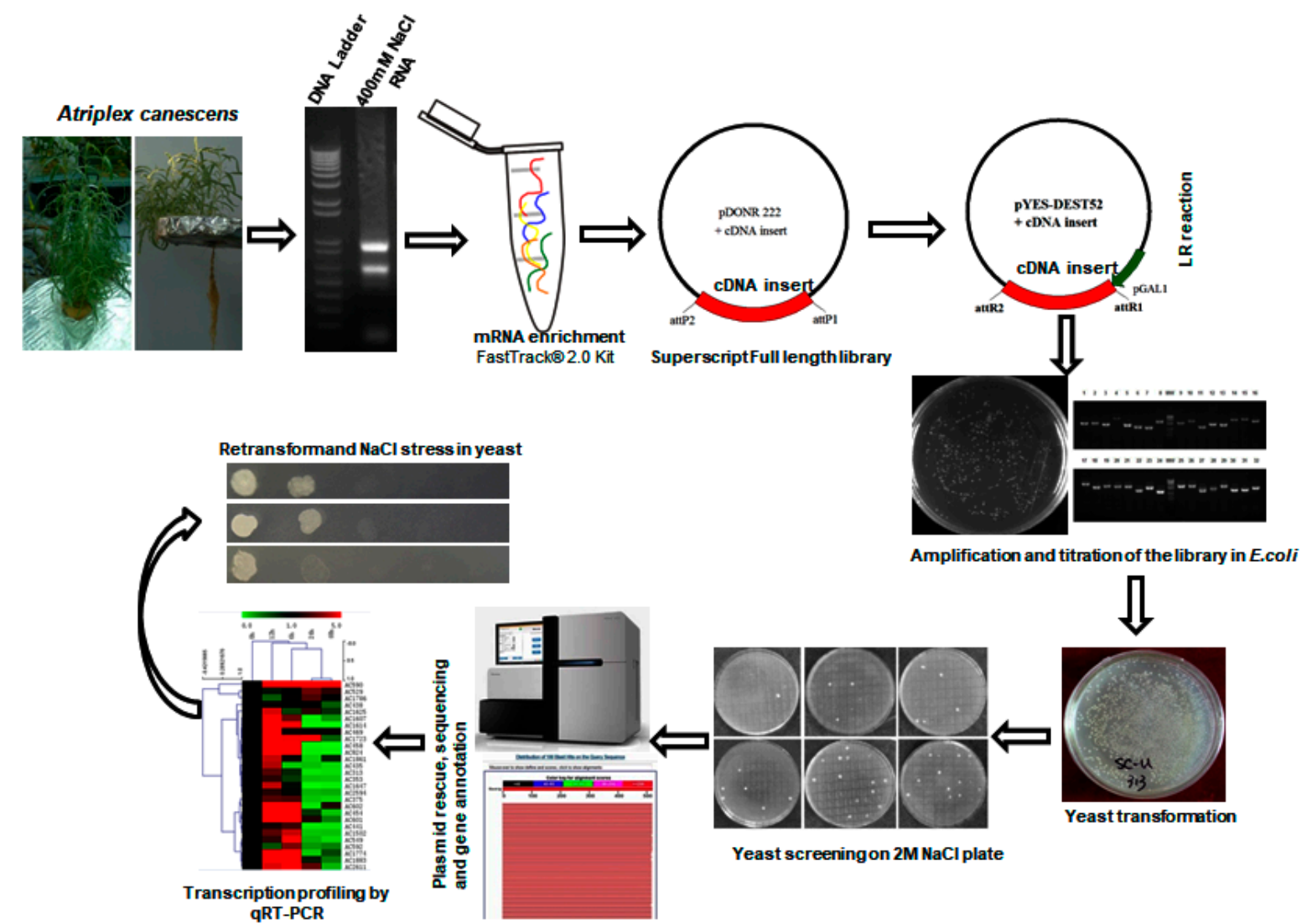

Figure 1. Schematic illustration of cDNA library construction and yeast functional screening. Generally, $400 \mathrm{mM} \mathrm{NaCl}$ treated A. canescens was subjected to RNA isolation and then cDNA library construction. The cDNA library pool was transformed into yeast cells and subsequently treated with salt under induction conditions. Finally, the survived yeast was turned to plasmid preparation and the plasmids were sent for sequencing and bioinformatics analyses.

Table 1. General information $A$. canescens full-length cDNA library. Recombinant rate represents the percentage of cDNA inserts in plasmid checked by PCR and electrophoresis.

\begin{tabular}{ccccc}
\hline cDNA library & Vector & CFU & $\begin{array}{c}\text { Average Inserted } \\
\text { Fragment }\end{array}$ & $\begin{array}{c}\text { Recombinant } \\
\text { Rate }\end{array}$ \\
\hline Primary cDNA library & pDONR222 & $1.76 \times 10^{6}$ & $>1 \mathrm{~kb}$ & $91 \%$ \\
Destination cDNA library & pYES-DEST52 & $1.624 \times 10^{7}$ & $>1 \mathrm{~kb}$ & $95 \%$ \\
\hline
\end{tabular}

\subsection{Identification of Salt Tolerance-Related Genes from A. canescens}

From initial screening, $2 \mathrm{M} \mathrm{NaCl}$ was chosen to use as a stringent selection concentration (Figure 2). As shown in Figure 3, 53 tolerant colonies were recovered (Figure 3) from approximately $1 \times 10^{5}$ yeast transformants on the Synthetic Complete without Uracil (SC-U) medium containing $2 \mathrm{M} \mathrm{NaCl}$, and most of the yeast were not able to survive on $2 \mathrm{M} \mathrm{NaCl}$ plates. Plasmids isolated from all 53 salt-tolerant yeast transformants were back-transformed into $E$. coli for propagation and sequencing. Insert sequences from all 53 yeast colonies were identified by BLAST analysis and the sequence information were deposited in GenBank. Corresponding GenBank accession numbers are listed in Table 2. Thirty-four out of these $53 \mathrm{cDNA}$ sequence contain the full ORF (open reading frame) (Table 2). All of these genes are homologous to the known genes in the other plants. Gene ontology (GO) classification of the isolated genes was performed to identify the functional processes. Overall, these isolated genes were mainly membrane associated and with binding and catalytic activity categories (Figure 4). 


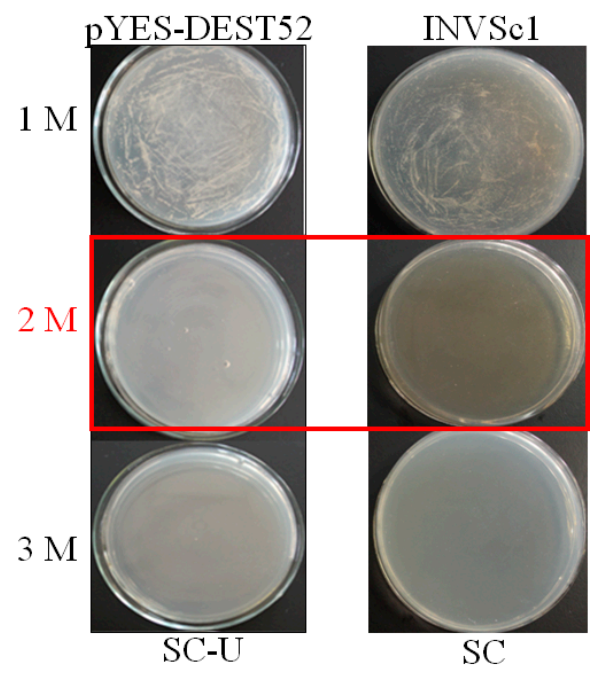

Figure 2. Optimization of $\mathrm{NaCl}$ concentrations for yeast functional screening. Yeast cells INVSc1 harboring pYES-DEST and control were induced with $2 \%$ galactose and streaked on Synthetic Complete without Uracil (SC-U) and SC medium, respectively. The plates were kept at $28{ }^{\circ} \mathrm{C}$ for $72 \mathrm{~h}$ and photographed. The concentration ( $2 \mathrm{M} \mathrm{NaCl}$ highlight in red) without emerging yeast colonies were used for screening.

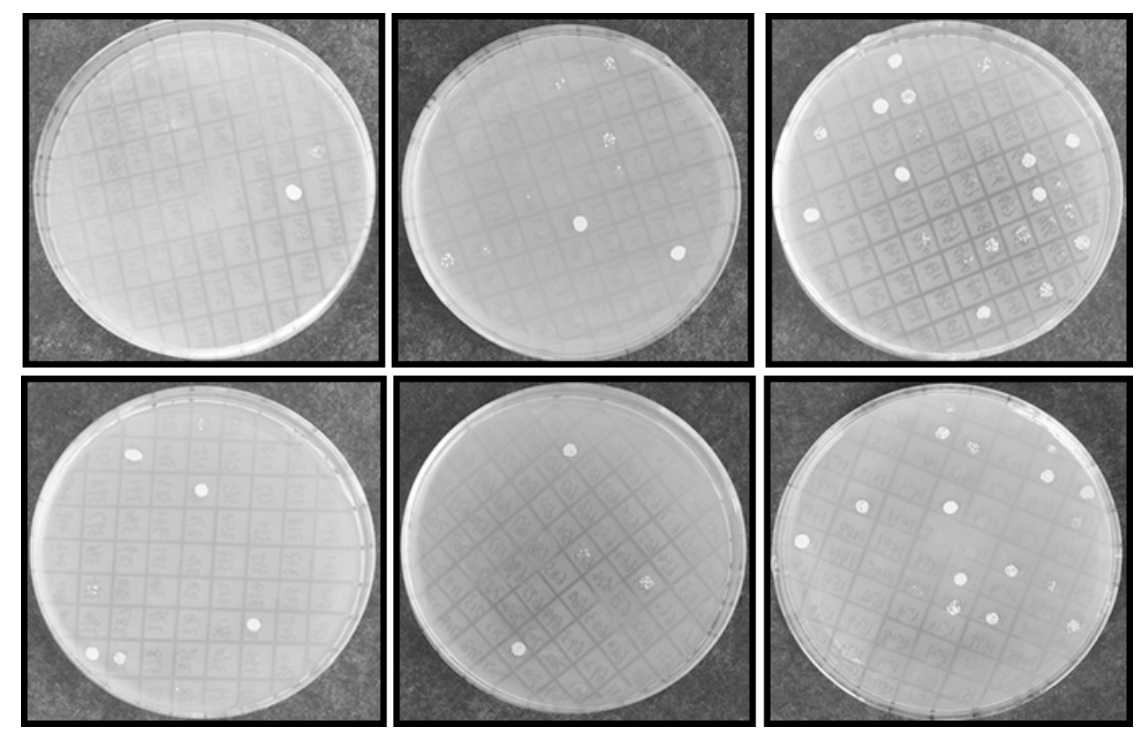

Figure 3. Yeast transformants exhibited $\mathrm{NaCl}$ resistance on SC-U plates. INVSc1 competent cells were transformed with library plasmid DNA and streaked on $2 \%$ glucose SC-U plate and incubated for $72 \mathrm{~h}$ at $28^{\circ} \mathrm{C}$. After yeast colony was visualized, more than $1 \times 10^{5}$ transformants were picked up randomly and induced with $2 \%$ galactose for $24 \mathrm{~h}, 2 \mu \mathrm{L}$ transformed yeast was spotted on SC-U solid plates $\left(2 \%\right.$ agar $+2 \%$ galactose) with $2 \mathrm{M} \mathrm{NaCl}$ and then incubate at $28^{\circ} \mathrm{C}$ for $72 \mathrm{~h}$ and photographed. 


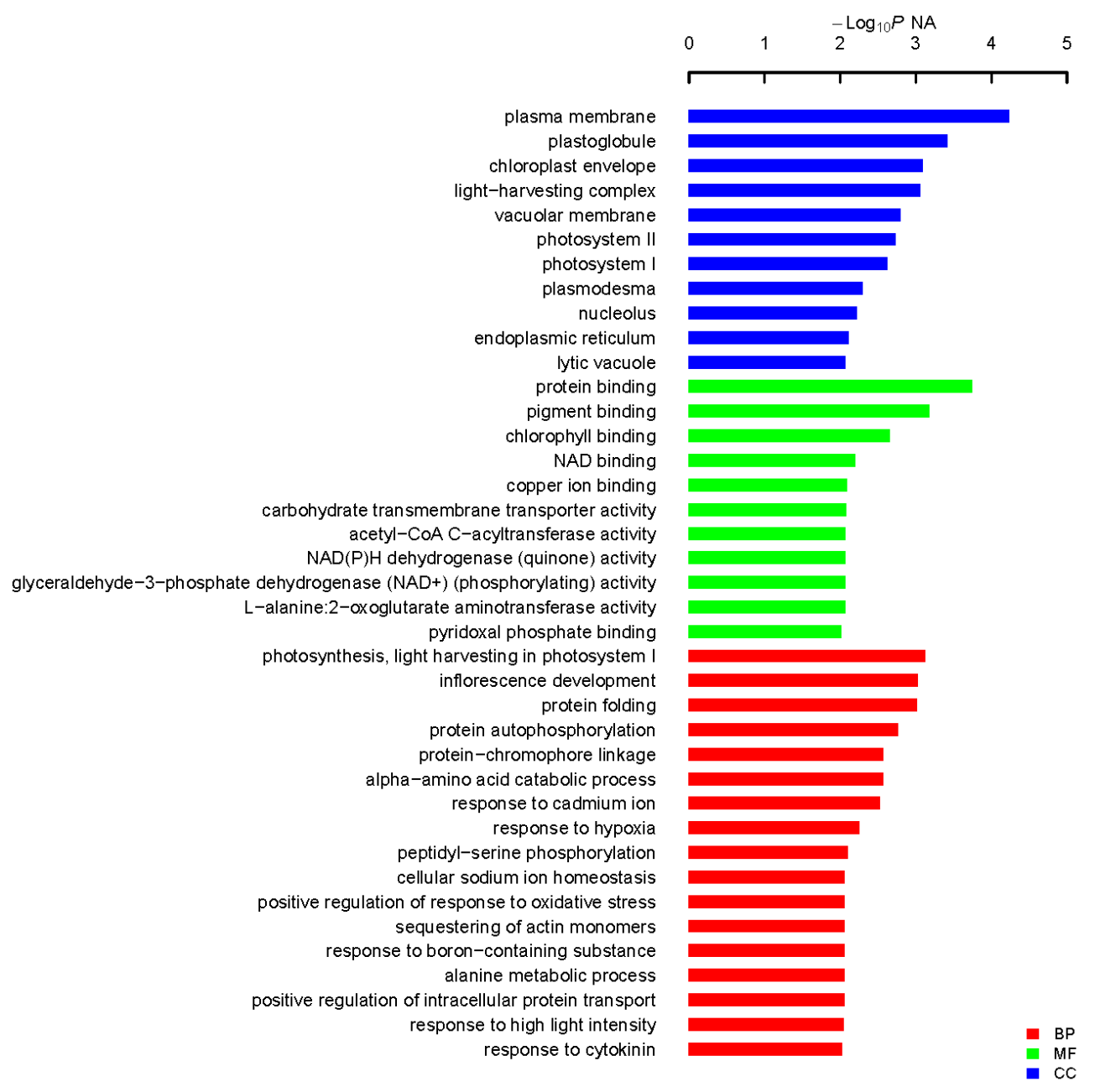

Figure 4. Functional categorization of isolated genes in A. canescens seedlings exposed to salinity. Fisher's exact test was used and $p<0.05$ was considered to indicate a statistically significant difference to identify biological process (BP), cellular component (CC) and molecular function (MF).

Table 2. Annotation of 53 isolated genes from A. canescens exploiting yeast functional screening system.

\begin{tabular}{|c|c|c|c|c|c|c|c|}
\hline Clone No. & $\begin{array}{c}\text { GenBank } \\
\text { Accession } \\
\text { No. }\end{array}$ & Putative Gene Function & $\begin{array}{l}\text { Organism } \\
\text { Matched }\end{array}$ & $\begin{array}{l}\text { Full-Length } \\
\text { ORF }\end{array}$ & $E$-Value & $\begin{array}{c}\text { Target } \\
\text { GenBank } \\
\text { Accession No. }\end{array}$ & $\begin{array}{c}\text { Recapturing } \\
\text { Salt } \\
\text { Resistance }\end{array}$ \\
\hline Ac113 & KJ026988 & Cysteine desulfurase & $\begin{array}{l}\text { Arabidopsis } \\
\text { thaliana }\end{array}$ & Yes & $2 \times 10^{-70}$ & NP_001078802.1 & No \\
\hline Ac151 & KJ026991 & $\begin{array}{l}\text { Phosphoglyceride transfer } \\
\text { family protein }\end{array}$ & $\begin{array}{l}\text { Theobroma } \\
\text { cacao }\end{array}$ & Yes & $5 \times 10^{-160}$ & EOY17339.1 & No \\
\hline Ac152 & KJ026992 & Cyclophilin & Suaeda salsa & Yes & $5 \times 10^{-92}$ & AGI78541.1 & Yes \\
\hline Ac273 & KJ026995 & Beta-amylase & $\begin{array}{l}\text { Ricinus } \\
\text { communis }\end{array}$ & Yes & $3 \times 10^{-21}$ & XP_002519919.1 & No \\
\hline Ac313 & KJ026998 & $\begin{array}{l}\text { Membrane-associated } \\
\text { progesterone binding protein }\end{array}$ & $\begin{array}{l}\text { Theobroma } \\
\text { cacao }\end{array}$ & Yes & $4 \times 10^{-46}$ & EOY29287.1 & Yes \\
\hline Ac315 & KJ027000 & $\begin{array}{l}\text { Signal recognition particle } \\
\text { receptor }\end{array}$ & $\begin{array}{l}\text { Theobroma } \\
\text { cacao }\end{array}$ & Yes & $7 \times 10^{-122}$ & EOY25233.1 & Yes \\
\hline Ac359 & KJ027004 & Cytochrome c1-1 & $\begin{array}{l}\text { Solanum } \\
\text { lycopersicum }\end{array}$ & Yes & $2 \times 10^{-174}$ & XP_004231797.1 & No \\
\hline Ac375 & KJ027006 & Glycogen synthase kinase-3 & $\begin{array}{l}\text { Ricinus } \\
\text { communis }\end{array}$ & No & $2 \times 10^{-149}$ & XP_002522231.1 & Yes \\
\hline
\end{tabular}


Table 2. Cont.

\begin{tabular}{|c|c|c|c|c|c|c|c|}
\hline Clone No. & $\begin{array}{l}\text { GenBank } \\
\text { Accession } \\
\text { No. }\end{array}$ & Putative Gene Function & $\begin{array}{l}\text { Organism } \\
\text { Matched }\end{array}$ & $\begin{array}{l}\text { Full-Length } \\
\text { ORF }\end{array}$ & $E$-Value & $\begin{array}{c}\text { Target } \\
\text { GenBank } \\
\text { Accession No. }\end{array}$ & $\begin{array}{c}\text { Recapturing } \\
\text { Salt } \\
\text { Resistance }\end{array}$ \\
\hline Ac392 & KJ027007 & $\begin{array}{c}\text { Major chlorophyll a/b } \\
\text { binding protein LHCb1.2 }\end{array}$ & $\begin{array}{l}\text { Spinacia } \\
\text { oleracea }\end{array}$ & Yes & 0 & CAJ77390.1 & No \\
\hline Ac435 & KJ027013 & $\begin{array}{l}\text { 3-ketoacyl-CoA thiolase } 2 \\
\text { peroxisomal-like }\end{array}$ & $\begin{array}{c}\text { Solanum } \\
\text { lycopersicum }\end{array}$ & Yes & 0 & XP_004247828.1 & Yes \\
\hline Ac438 & KJ027014 & Glycine-rich protein & Pisum sativum & Yes & $6 \times 10^{-3}$ & CAH40798.1 & Yes \\
\hline Ac441 & KJ027018 & Zinc metalloprotease & $\begin{array}{l}\text { Ricinus } \\
\text { communis }\end{array}$ & No & $4 \times 10^{-63}$ & XP_002518787.1 & Yes \\
\hline Ac454 & KJ027022 & $\begin{array}{l}\text { RNA-binding family protein } \\
\text { with retrovirus zinc } \\
\text { finger-like domain }\end{array}$ & $\begin{array}{l}\text { Theobroma } \\
\text { cacao }\end{array}$ & Yes & $2 \times 10^{-66}$ & EOY18432.1 & Yes \\
\hline Ac458 & KJ027023 & Cytochrome P450 & $\begin{array}{l}\text { Populus } \\
\text { trichocarpa }\end{array}$ & Yes & $1 \times 10^{-104}$ & XP_002334834.1 & Yes \\
\hline Ac469 & KJ027025 & $\begin{array}{l}\text { Oxygen-evolving enhancer } \\
\text { protein } 3\end{array}$ & $\begin{array}{l}\text { Spinacia } \\
\text { oleracea }\end{array}$ & Yes & $8 \times 10^{-130}$ & P12301.1 & Yes \\
\hline Ac529 & KJ027035 & $\begin{array}{c}\text { Temperature-induced } \\
\text { lipocalin }\end{array}$ & $\begin{array}{l}\text { Populus } \\
\text { balsamifera }\end{array}$ & Yes & $2 \times 10^{-80}$ & ABB02389.1 & Yes \\
\hline Ac549 & KJ027036 & $\begin{array}{l}\text { Late embryogenesis } \\
\text { abundant protein }\end{array}$ & $\begin{array}{l}\text { Ricinus } \\
\text { communis }\end{array}$ & Yes & $5 \times 10^{-07}$ & XP_002509455.1 & Yes \\
\hline Ac567 & KJ027038 & Polyubiquitin family protein & $\begin{array}{l}\text { Populus } \\
\text { trichocarpa }\end{array}$ & No & 0 & XP_006372519.1 & No \\
\hline Ac574 & KJ027042 & $\begin{array}{l}\text { Tetratricopeptide repeat } \\
\text { (TPR)-like superfamily } \\
\text { protein }\end{array}$ & $\begin{array}{l}\text { Theobroma } \\
\text { cacao }\end{array}$ & Yes & $2 \times 10^{-104}$ & EOY31556.1 & Yes \\
\hline Ac590 & KJ027045 & Ubiquitin & $\begin{array}{l}\text { Arabidopsis } \\
\text { thaliana }\end{array}$ & No & $4 \times 10^{-55}$ & АВH08753.1 & Yes \\
\hline Ac592 & KJ027046 & $\begin{array}{l}\text { Zinc finger (C3HC4-type } \\
\text { RING finger) family protein }\end{array}$ & $\begin{array}{l}\text { Arabidopsis } \\
\text { thaliana }\end{array}$ & Yes & $1 \times 10^{-94}$ & NP_564060.1 & Yes \\
\hline Ac601 & KJ027047 & $\begin{array}{l}\text { ARF domain class } \\
\text { transcription factor }\end{array}$ & $\begin{array}{l}\text { Malus } \\
\text { domestica }\end{array}$ & No & $4 \times 10^{-88}$ & ADL36578.1 & Yes \\
\hline Ac603 & KJ027048 & $\begin{array}{l}\text { Dehydration-responsive } \\
\text { element binding protein }\end{array}$ & $\begin{array}{l}\text { Atriplex } \\
\text { canescens }\end{array}$ & Yes & 0 & AEW68339.1 & No \\
\hline Ac602 & KJ027049 & Cysteine proteinase A494 & $\begin{array}{l}\text { Populus } \\
\text { trichocarpa }\end{array}$ & Yes & 0 & XP_002305451.2 & Yes \\
\hline Ac622 & KJ027051 & $\begin{array}{l}\text { AP2-like ethylene-responsive } \\
\text { transcription factor }\end{array}$ & $\begin{array}{l}\text { Medicago } \\
\text { truncatula }\end{array}$ & No & $1 \times 10^{-63}$ & XP_003625138.1 & Yes \\
\hline Ac799 & KJ027055 & $\begin{array}{l}\text { S-adenosyl-L-homocysteine } \\
\text { hydrolase }\end{array}$ & Beta vulgaris & Yes & 0 & BAE07182.1 & No \\
\hline Ac809 & KJ027057 & Alanine aminotransferase 2 & $\begin{array}{l}\text { Theobroma } \\
\text { cacao }\end{array}$ & Yes & $3 \times 10^{-113}$ & EOY27390.1 & Yes \\
\hline Ac812 & KJ027058 & $\begin{array}{l}\text { Armadillo/beta-catenin } \\
\text { repeat family protein }\end{array}$ & $\begin{array}{l}\text { Theobroma } \\
\text { cacao }\end{array}$ & Yes & $3 \times 10^{-115}$ & EOY18778.1 & Yes \\
\hline Ac824 & KJ027061 & Hexose transporter & $\begin{array}{c}\text { Elaeis } \\
\text { guineensis }\end{array}$ & Yes & $8 \times 10^{-123}$ & AEQ94177.1 & Yes \\
\hline Ac1455 & KJ027067 & $\begin{array}{l}\text { Zinc finger and BTB } \\
\text { domain-containing protein }\end{array}$ & $\begin{array}{l}\text { Theobroma } \\
\text { cacao }\end{array}$ & No & $2 \times 10^{-61}$ & EOY17025.1 & Yes \\
\hline Ac1458 & KJ027069 & Thiamin biosynthetic enzyme & Glycine max & Yes & 0 & BAA88226.1 & No \\
\hline Ac1463 & KJ027070 & GTP-binding protein sar1 & $\begin{array}{l}\text { Ricinus } \\
\text { communis }\end{array}$ & No & $1 \times 10^{-121}$ & XP_002515297.1 & Yes \\
\hline Ac1476 & KJ027073 & $\begin{array}{l}\text { Nonspecific lipid-transfer } \\
\text { protein-like protein } \\
\text { At2g13820-like }\end{array}$ & Vitis vinifera & No & $9 \times 10^{-35}$ & XP_003632312.1 & Yes \\
\hline Ac1502 & KJ027076 & $\begin{array}{l}\mathrm{NAD}(\mathrm{P}) \mathrm{H} \text { dehydrogenase } \mathrm{C} 1 \\
\text { isoform } 2\end{array}$ & $\begin{array}{c}\text { Theobroma } \\
\text { cacao }\end{array}$ & No & $7 \times 10^{-153}$ & EOX92707.1 & Yes \\
\hline Ac1607 & KJ027083 & Profilin & $\begin{array}{l}\text { Chenopodium } \\
\text { album }\end{array}$ & No & $6 \times 10^{-83}$ & Q84V37.1 & Yes \\
\hline Ac1614 & KJ027084 & $\begin{array}{l}\text { Leucine-rich repeat protein } \\
\text { kinase family protein }\end{array}$ & $\begin{array}{l}\text { Arabidopsis } \\
\text { thaliana }\end{array}$ & No & $3 \times 10^{-27}$ & NP_190219.1 & Yes \\
\hline Ac1625 & KJ027085 & $\begin{array}{l}\text { eukaryotic elongation factor } \\
1 \mathrm{~A}\end{array}$ & $\begin{array}{c}\text { Salsola } \\
\text { komarovii }\end{array}$ & No & $2 \times 10^{-160}$ & BAC22127.1 & Yes \\
\hline Ac1637 & KJ027087 & Ferredoxin-1 & $\begin{array}{l}\text { Mesembryanthemum } \\
\text { crystallinum }\end{array}$ & No & $4 \times 10^{-66}$ & O04683.1 & No \\
\hline Ac1647 & KJ027088 & RNA-binding family protein & $\begin{array}{l}\text { Theobroma } \\
\text { cacao }\end{array}$ & Yes & $4 \times 10^{-71}$ & EOY04889.1 & Yes \\
\hline Ac1723 & KJ027090 & $\begin{array}{c}\text { Late embryogenesis } \\
\text { abundant protein D-113 }\end{array}$ & $\begin{array}{l}\text { Gossypium } \\
\text { hirsutum }\end{array}$ & No & $1 \times 10^{-6}$ & P09441.2 & Yes \\
\hline Ac1737 & KJ027095 & $\begin{array}{l}\text { Glyceraldehyde-3-phosphate } \\
\text { dehydrogenase }\end{array}$ & $\begin{array}{l}\text { Atriplex } \\
\text { nummularia }\end{array}$ & No & 0 & P34783.1 & No \\
\hline Ac1752 & KJ027097 & $\begin{array}{c}\text { Putative ankyrin-repeat } \\
\text { protein }\end{array}$ & Vitis aestivalis & No & $4 \times 10^{-104}$ & AAQ96339.1 & No \\
\hline Ac1774 & KJ027102 & Cysteine proteinases & $\begin{array}{l}\text { Theobroma } \\
\text { cacao }\end{array}$ & Yes & $4 \times 10^{-115}$ & EOX95504.1 & Yes \\
\hline Ac1786 & KJ027105 & $\begin{array}{c}\text { Calcium-dependent } \\
\text { lipid-binding (CaLB domain) } \\
\text { plant } \\
\text { phosphoribosyltransferase }\end{array}$ & $\begin{array}{l}\text { Theobroma } \\
\text { cacao }\end{array}$ & Yes & 0 & EOY09444.1 & Yes \\
\hline Ac1861 & KJ027110 & $\begin{array}{l}\text { calmodulin } 1 \\
\text { pald }\end{array}$ & Zea mays & Yes & $5 \times 10^{-98}$ & AFW78488.1 & Yes \\
\hline
\end{tabular}


Table 2. Cont.

\begin{tabular}{|c|c|c|c|c|c|c|c|}
\hline Clone No. & $\begin{array}{c}\text { GenBank } \\
\text { Accession } \\
\text { No. }\end{array}$ & Putative Gene Function & $\begin{array}{l}\text { Organism } \\
\text { Matched }\end{array}$ & $\begin{array}{l}\text { Full-Length } \\
\text { ORF }\end{array}$ & E-Value & $\begin{array}{c}\text { Target } \\
\text { GenBank } \\
\text { Accession No. }\end{array}$ & $\begin{array}{c}\text { Recapturing } \\
\text { Salt } \\
\text { Resistance }\end{array}$ \\
\hline Ac1883 & KJ027112 & $\begin{array}{l}\text { Abscisic acid stress ripening } \\
\text { protein }\end{array}$ & $\begin{array}{l}\text { Mesembryanthemum } \\
\text { crystallinum }\end{array}$ & Yes & $9 \times 10^{-5}$ & AAC14177.1 & Yes \\
\hline Ac1913 & KJ027114 & $\begin{array}{l}\text { Non-specific lipid-transfer } \\
\text { protein }\end{array}$ & Beta vulgaris & Yes & $2 \times 10^{-24}$ & Q43748.1 & Yes \\
\hline Ac2594 & KJ027115 & $\begin{array}{l}\text { Aquaporin NIP6.1 family } \\
\text { protein }\end{array}$ & $\begin{array}{l}\text { Populus } \\
\text { trichocarpa }\end{array}$ & Yes & $6 \times 10^{-135}$ & XP_002304723.1 & Yes \\
\hline Ac2611 & KJ027117 & $\begin{array}{l}23 \mathrm{kDa} \text { precursor protein of } \\
\text { the oxygen-evolving complex }\end{array}$ & $\begin{array}{l}\text { Salicornia } \\
\text { europaea }\end{array}$ & Yes & $4 \times 10^{-155}$ & BAG70022.1 & Yes \\
\hline
\end{tabular}

\subsection{Expression Profiles of Selected Salt Resistance Genes under Abiotic Stress}

In order to investigate expression profiles of isolated salt resistance genes under salt treatment, total RNA was isolated from leaf tissues of $A$. canescens that had been treated with $400 \mathrm{mM} \mathrm{NaCl}$ for various time points $(0,6,12,24$ and $48 \mathrm{~h})$ and subjected to cDNA synthesis and real-time PCR (Figure 5 and Figure $\mathrm{S} 1$ in the Supplementary Material). From the qRT-PCR data, most of the selected genes ( 28 genes) could be induced by salt treatment at an early time point $(6 \mathrm{~h}, 12 \mathrm{~h})$, transcript accumulation at highest level was $12 \mathrm{~h}$ after treatment, and transcript signals decreased from 24 to $48 \mathrm{~h}$ after treatment. Transcript accumulation increase varied from 1- to 70-fold for different genes. Furthermore, the expression patterns under drought and cold treatment for these selected genes were investigated by qRT-PCR as well. Two-thirds of the genes (16/28) induced by salt could be induced by drought treatment as well (Figure 5 and Figure S2 in the Supplementary Material). Only seven genes induced by salt could be induced by low temperature treatment (Figure 5 and Figure S3 in the Supplementary Material). Only one gene among them, encoding a late embryogenesis abundant protein, could be induced by all these three treatments simultaneously (Figure S4 in the Supplementary Material).
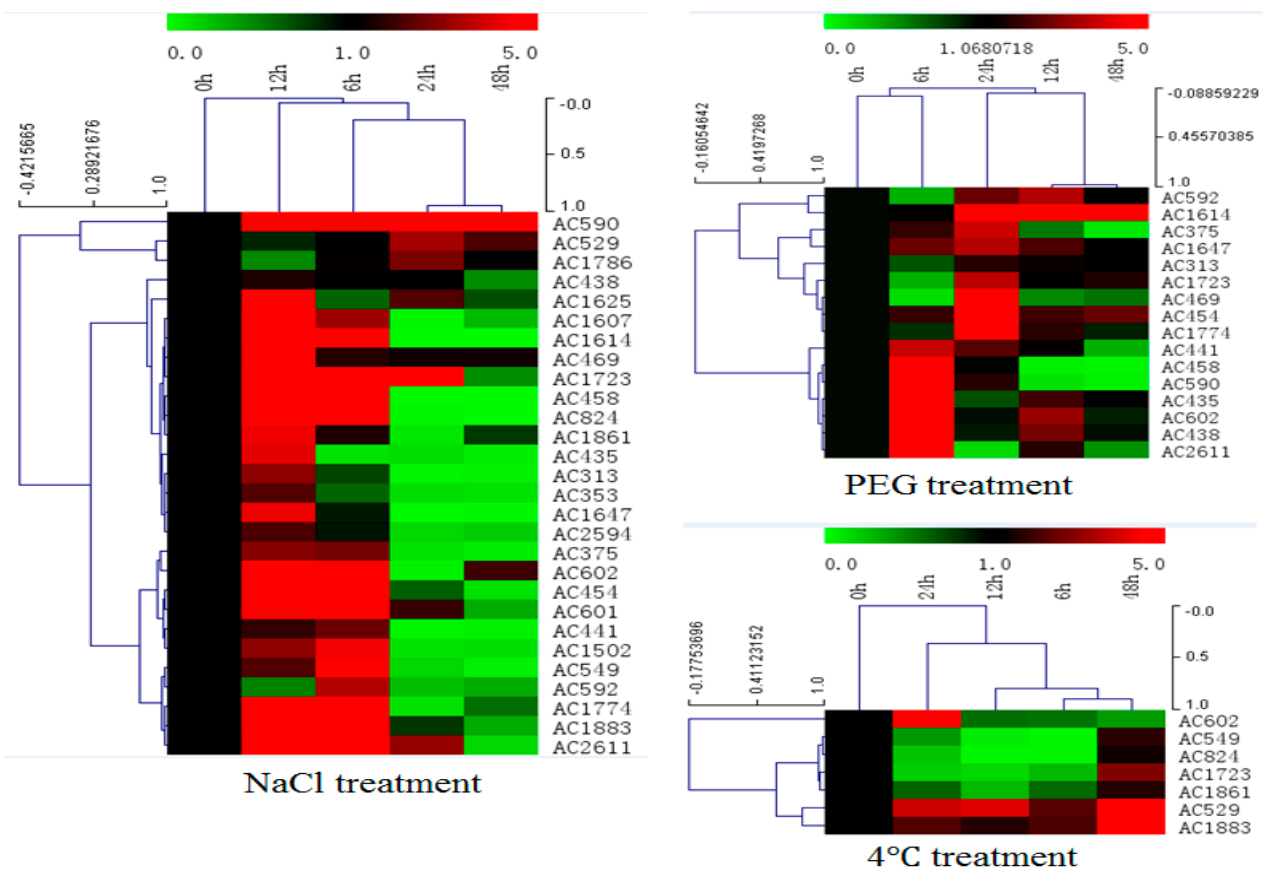

Figure 5. Gene expression profiles of 28 isolated genes in A. canescens under various stressors by quantitative real-time RT-PCR analysis. Hierarchical clustering was built using $\mathrm{MeV}$ software. Each gene is demonstrated by a single row of colored boxes, and a single column represents different time points with stress treatment. The scale representing the relative signal intensity values is shown above. Induction (or repression) ranges from pale to saturated red (or green) with a fold change scale bar (in $\log 2$ ) shown up the clusters. 


\subsection{Recapturing Salt Resistance Assay of Isolated Genes}

The isolated plasmids were retransformed into new yeast cells individually and salt resistance capacity was retested by spotting those induced yeast cells on SC-U medium containing $2 \mathrm{M} \mathrm{NaCl}$ (Figure 6) under conditions in which yeast cells containing pYES-DEST52 (control) were not able to survive. Most of tested pYES2-Acgenes (39/53, 73.6\%) retained the ability to survive on SC-U medium with salt (Table 2). The genes that exhibited upregulated expression profiles in Figure 5 showed the capacity to survive on the salt-stressed SC-U medium. Under these conditions, the retransformed yeast cells survived $2 \mathrm{M} \mathrm{NaCl}$ stress after 1:10 dilution, but rarely at further diluted concentrations, which might be because of the stringent $\mathrm{NaCl}$ concentrations.

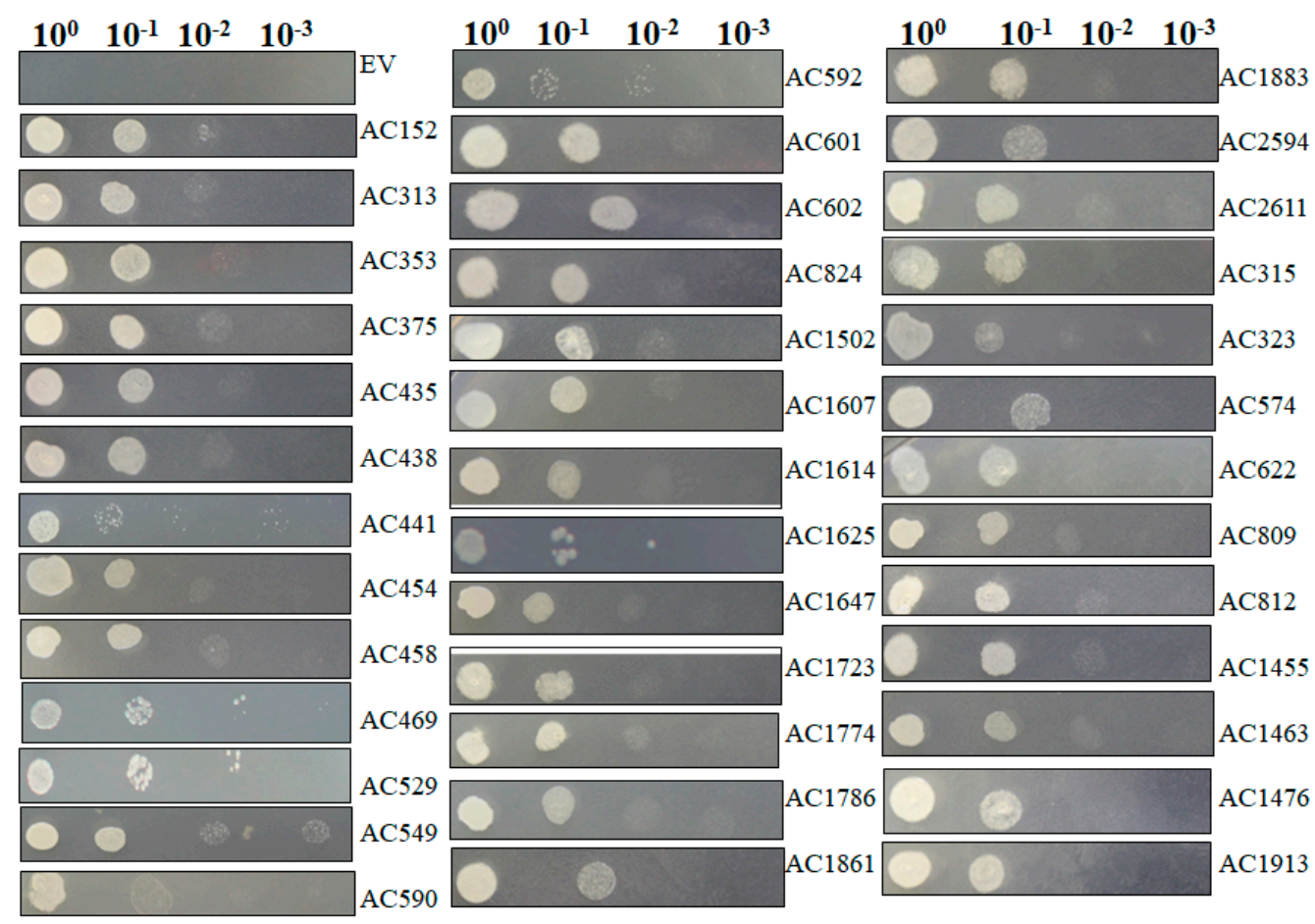

Figure 6. Functional analyses of selected salt resistance related genes in transformed yeast cells. Salt resistance related genes screened from primary screening in large scale selection were retransformed into yeast cells. Then the induced yeast was spotted with a series of dilutions on SC-U plate plus $2 \mathrm{M}$ $\mathrm{NaCl}$. Photographs were taken 72 hpi.

\section{Discussion}

Salinity stress limits plant growth and development, leading to productivity loss. An understanding of plant abiotic stress responses, including determinants of salt stress tolerance, would be of importance for both basic and applied plant science research [21]. The woody halophyte Atriplex species, including A. canescens, are well-known bushes for their tolerance to salinity, drought, heavy metals and extreme temperature and are considered to serve as a potential candidate for the salt-responsive genes and promoters $[3,14]$. A few reports described abiotic stress related genes isolated from A. canescens. We characterized a heavy metal-resistant protein AcHMA1 from A. canescens and transgenic yeast cells harboring AcHMA1 showed a significantly improved survival rates on medium supplemented with iron, salt, alkaline, osmotic and oxidant stress [22]. Another two reports from our lab identified AcNIP5; 1 and AcPIP2, two isoforms of aquaporin from A. canescens, which altered the resistance phenotypes in transgenic $A$. thaliana plants in the face of either drought or salt stress [23,24]. More recently, an ErbB3-binding protein, AcEBP1 from A. canescens, was demonstrated to function as a negative regulator responding to salt and osmotic stress [25]. 
In order to further explore molecular determinants of salt tolerance in A. canescens, a gateway cloning system compatible cDNA library was generated from $A$. canescens plants exposed to $400 \mathrm{mM}$ $\mathrm{NaCl}$ [20]. $400 \mathrm{mM} \mathrm{NaCl}$ is high concentration for plants, but it does not affect $A$. canescens' normal growth, which could significantly enhance $A$. canescens' leaf osmotic potential compared to the control plants with no salt treatment in a recent report [26]. Lasting salt treatment, such as 48-h exogenous application, could allow us to isolate abundant and important salt tolerance determinants. In the present study, we cloned the cDNA library into a yeast expression system, followed by yeast S. cerevisiae INVSc1 transformation. Yeast expression system was proved to be a rapid and robust assay system for large-scale screening of genes for abiotic stress tolerance with attractive features like rapid growth in culture, eukaryotic expression and conserved signaling and regulatory pathways, and post-translational modification process with the advantage of facile genetic manipulation [16-18,27]. Heterologous gene expression taking use of the conserved signaling and regulatory pathways to manipulate the yeast behaviors in response to stimuli allows us to investigate every single salt determinant. The transformed yeasts were stressed with $2 \mathrm{M} \mathrm{NaCl}$ and 53 single genes responsible for salt tolerance in transgenic yeasts were rescued. Most of the isolated genes were found to be homologues of proteins known to be associated with stress tolerance in other plant systems, including late embryogenesis abundant proteins (LEAs), transporters, DNA/RNA-binding proteins, proteases, osmotic regulation proteins, photosynthesis-related proteins and enzymes related to metabolism (Table 2). Thirty-nine of the isolated total 53 genes recapture the salt tolerance in re-transformed yeasts (Figure 6), correlated to the expression profiles demonstrated by qRT-PCR after $400 \mathrm{mM}$ salt treatment in A. canescens for those genes (Figure 5). Halophytes are famous for their higher salt-adaptive plasticity and special evolved salt glands, enabling elimination or sequestration of extra salt from metabolically active tissues [28]. In the presence of excess salt for glycophyte, the halophytes, such as $A$. canescens (like $400 \mathrm{mM} \mathrm{NaCl}$ in our condition), display optimum growth may be due to constitutive expression of genes that encode salt-tolerance determinants [29], or may be due to the adaptive and rapid regulation of gene expression in response to salt, which is consistent to our observations in this study. The qRT-PCR data revealed that the tested genes are responding to salt stress rapidly (within $6 \mathrm{~h}$ ) and then probably are translated into the corresponding proteins, functioning to maintain the ion homeostasis, leading to the transcripts abundance reduction $24 \mathrm{~h}$ after salt stress application.

In this study, most of the isolated gene encoding proteins were enriched in plasma membrane associated category with protein binding activity after GO analysis (Figure 4). Among them, three genes encoding proteins with transporting activities were isolated: $\mathrm{K}^{+}$uptake permease, hexose transporter and aquaporin NIP6.1 were isolated, which indicate the roles of transporter in plant adaption to salt stress. Transporters could facilitate the absorption of $\mathrm{H}_{2} \mathrm{O}$ and mineral nutrients to enable the maintenance of intracellular homeostasis [30-32]. Intriguingly, the largest group of proteins were enriched in photosynthesis, light harvesting in photosystem I in biological process in our GO analysis, indicative the roles of photosynthesis-related proteins in plant response to salt stress. Sugihara et al. characterized an oxygen evolving enhancer protein 1 from mangrove Bruguiera gymnorrhiza treated with $500 \mathrm{mM} \mathrm{NaCl}$ after two-dimensional gel electrophoresis and showed that the quantity of this protein increased after salt treatment [33]. One of our studies [34] demonstrated transgenic yeast cells expressing AcPsbQ1 (Ac469 in this study) exhibited better salt- and drought-stress survival rates. Transcriptomic and proteomic studies have shown that the expression levels of photosystem related proteins could be increased by abiotic stress at both transcriptional and translational level [9]. Under saline environments, A. canescens exhibits enhanced photosynthetic capacity in terms of increased net photosynthetic rate and water use efficiency [26], which was also reported in another halophyte C. glauca $[6,8]$. However, how the photosynthesis-related genes take use of the host yeast signaling pathways to play functions leading to enhanced yeast cell survival rates upon salt treatment is still unknown. Taken together, these studies indicate that photosystem proteins might play secondary roles in abiotic stress resistance in plants. However, the underlying functions and mechanisms of those proteins in plant abiotic stress resistance remains to be determined. Transcription factors (TFs), 
including an AP2-like ethylene-responsive TF (ERF), a zinc finger (C3HC4-type RING finger) family protein and an auxin-responsive factor (ARF) domain class TF, were isolated in our work. Regularly, TFs are considered to function as signaling regulator to manipulate transduction networks, there are emerging studies demonstrating that TFs are also responsible for stress tolerance when expressed in yeast $[16,22,27]$. A dehydration responsive element-binding factor (DREB) TF ZmDBF3 from maize (Zea mays L.) was demonstrated to increase host survival ability to salt, osmotic and extreme temperature stress when expressed in E. coli, yeast and Arabidopsis [35]. EsDREB2B, a DREB TF from Eremosparton songoricum, dramatically improved host yeast cells growth compared to the control yeast when stressed with Polyethylene glycol (PEG), NaCl, and heat [36]. Four protein members (ScDREB3, ScDREB5, ScDREB8, and ScDREB10) from the A-5 subgroup of the DREB subfamily in a typical desert moss, Syntrichia caninervis, enhanced the yeast's salt, drought, or cold tolerance [37]. These well-demonstrated examples revealed that TFs may function in yeast expression system via regulating conserved signaling pathway. Late embryogenesis abundant (LEA) proteins have long been associated with abiotic stress in plants. In our screen, two different LEA proteins were isolated and the transformed yeast cells recaptured salt stress tolerance, of which the transcription level were found to be positively regulated by salt stress and low temperature (Figure 5 and Figure S3 in the Supplementary Material). One LEA gene (Ac1723) is the only gene isolated in this study that is responsive to salt, drought and cold stress treatment. LEA proteins are typically stress inducible and several studies have confirmed LEA proteins act as water-binding molecules that function in ion sequestration, in macromolecule membrane stabilization and in preventing molecular denaturation [38,39].

In this study, we employed yeast expression system to isolate salt tolerance-related genes from halophyte $A$. canescens and the separated genes are capable to enhance the survival capacity in transformed yeast cells and the gene expression are responsive to salt stress treatment. However, yeast-specific glycosylation and other post-translational modifications may be different from modifications found in plant systems [40]. Our further work will focus on characterization of the functionalities of these isolated genes in the context of plant expression system, in order to more fully characterize salt resistance in halophytes.

\section{Materials and Methods}

\subsection{Plant Materials, Plasmid, Yeast and Escherichia coli Strains, Medium}

Xero-halophyte $A$. canescens was used in this study and the cDNA library generation was described in our previous report [20]. Briefly, surface-sterilized seeds were germinated and the seedlings were transferred to $1 / 2$ Hoagland ( $\mathrm{pH}$ 6.0) solution in controlled environmental facility. After 50 days of growth, plants were then subjected to $400 \mathrm{mM} \mathrm{NaCl}$ treatment for $48 \mathrm{~h}$, and the harvested samples (young leaves and stems) were immediately frozen with liquid nitrogen and kept at $-80{ }^{\circ} \mathrm{C}$ for RNA preparation and cDNA library construction. The gateway system compatible vector pDONR222 was used for entry cloning and pYES-DEST52 [20] was used for functional expression in yeast. The E. coli strain DB3.1 was used to maintain the gateway compatible backbones pDONR222 and pYES-DEST52 with a $c c d B$ cassette. And E. coli DH10B competent cells were used to propagate and maintain both pDONR222 harboring cDNA library and pYES-DEST52-genes library. The yeast $S$. cerevisiae strain INVSc1 (MATa his3D1 leu2 trp1-289 ura3-52 MAThis3D1 leu2 trp1-289 ura3-52) was employed in this study (Invitrogen, Shanghai, China). Yeast cells were grown in either YPDA medium (with $2 \%$ glucose, $2 \%$ peptone, $1 \%$ yeast extract and $2 \%$ agar) or on an uracil-deficient synthetic complete (SC-U) medium (Fungenome Co., Beijing, China) with $2 \%(w / v)$ glucose for normal growth or $2 \%(w / v)$ galactose during induction and selection at $28^{\circ} \mathrm{C}$.

\subsection{Yeast Functional Screening to Select the Salinity Tolerant Transformants}

To express the cDNA library in yeast, a plasmid mixture harboring cDNA library was introduced into 10 vials of $100 \mu \mathrm{L}$ INVSc1 competent cells using a PEG-lithium acetate method and the resultant 
transformed yeast was streaked on $2 \%$ glucose SC-U plate and incubated for $48-72 \mathrm{~h}$ at $28^{\circ} \mathrm{C}$. After yeast colony was visualized, more than $1 \times 10^{5}$ transformants were picked up randomly and inoculated into $500 \mu \mathrm{L} \mathrm{SC}-\mathrm{U}\left(+2 \%\right.$ galactose) in $1.5 \mathrm{~mL}$ Eppendorf individually with a $200 \mathrm{rpm}$ shaking at $28^{\circ} \mathrm{C}$. After $24 \mathrm{~h}$ inoculation, $2 \mu \mathrm{L}$ transformed yeast was spotted on SC-U plates ( $2 \%$ agar $+2 \%$ galactose) with $2 \mathrm{M} \mathrm{NaCl}$ and then incubated at $28^{\circ} \mathrm{C}$ for $48-72 \mathrm{~h}$ and photographed.

Before screening of salt-related transformants, an optimization of salt selection concentration was performed. Generally, INVSc1 with pYES-DEST52 and INVSc1 alone were streaked on SC-U or SC agar plates plus $2 \%$ galactose and various $\mathrm{NaCl}$ concentrations $(1 \mathrm{M}, 2 \mathrm{M}$ and $3 \mathrm{M})$ and then grown at $28^{\circ} \mathrm{C}$ for colony visualization.

\subsection{Plasmid Rescue, Sequencing and Data Analysis}

Isolated yeast transformants were grown each in $10 \mathrm{~mL} \mathrm{SC-U}$ medium containing $2 \%$ glucose for $24 \mathrm{~h}$ with a $200 \mathrm{rpm}$ shaking at $28^{\circ} \mathrm{C}$. The pellets were then subjected to $50 \mathrm{U} / \mu \mathrm{L}$ lyticase (Sigma-Aldrich, St. Louis, MO, USA) and $1 \mathrm{M}$ sorbitol to generate protoplast, and then lysed with $200 \mathrm{mM} \mathrm{NaOH}$ and $10 \mathrm{~g} / \mathrm{L}$ SDS. Nucleic acid fraction recovered from yeast were purified with two sequential rounds of phenol: chloroform: isopropanol (25:24:1) extraction, followed by isopropyl alcohol precipitation of nucleic acids. To analyze the inserts cloned into pYES-DEST52 based yeast expression plasmid, nucleic acid preparations recovered from individual yeast transformants showing resistance to salinity stress were back transformed into E. coli DH5 $\alpha$ via electroporation (Gene Pulser Xcell Electroporation System, BioRad, Hercules, CA, USA). E. coli back transformants were analyzed for the presence of inserts by colony PCR with primer pair T7 and pYES-R (Table S1) on the backbone pYES-DEST52. E. coli re-transformants were then subjected to plasmid-prep and sequencing. Sequencing of Atriplex cDNA conferring salinity tolerance was performed at Beijing Genomic Institute, China, with primer pair T7 and pYES-R (Table S1). After sequencing, vector sequences were trimmed using SeqMan II (DNASTAR, Inc., Madison, WI, USA) and NCBI VecScreen (http://www.ncbi.nlm.nih.gov/tools/vecscreen/). Trimmed cDNA sequences were assembled using Vector NTI (Invitrogen, Carlsbad, CA, USA). Contigs were built using the CAP3 assembly program [41] with the parameters set at $95 \%$ identity over $40 \mathrm{bp}$. Individual processed unique genes were proceeded to Basic Local Alignment Search Tool (BLASTX) analysis against the non-redundant (nr) database (http:/ / www.ncbi.nlm.nih.gov) with a cut-off $E$-value $\leq 10^{-5}$. All consequential Atriplex sequences were then deposited in GenBank database and were subjected to data analyses.

\subsection{Functional Annotation and Categorization}

The complete sequence of the $A$. canescens genome is not yet available, whereas that of model dicotyledon plant $A$. thaliana is available, and its bioinformatics tools are available online. All the Atriplex cDNA sequences isolated were matched to A. thaliana transcripts manually (https:/ /www. arabidopsis.org/). For each encoded predicted peptide, the most similar one with lowest $E$-value was considered to be the best match. Gene ontology (GO) information were extracted from GO annotation file downloaded from the TAIR website online (http://www.arabidopsis.org/). GO enrichment was conducted to identify the related biological modules. Fisher's exact test was used and $p<0.05$ was considered to indicate a statistically significant difference to identify the three principles of GO, including "Biological Process" (BP), "Cellular Component" (CC) and "Molecular Function" (MF).

\subsection{Quantitative RT-PCR Validation of Salt-Related Genes}

The expression profiles after salt treatment of isolated salinity resistance candidate genes were investigated by performing qRT-PCR. Two month-old well-grown and healthy A. canescens cultured in Hoagland solution were complemented with different abiotic stressors ( $400 \mathrm{mM} \mathrm{NaCl}, 20 \%$ PEG6000 $(w / v)$ or $\left.4{ }^{\circ} \mathrm{C}\right)$ and nontreated control, respectively. Young leaves and stems, the materials of which we used for cDNA library construction, were sampled at $0,6,12,24$ and $48 \mathrm{~h}$ after stress treatments, and were immediately snap-frozen in liquid nitrogen and stored at $-80^{\circ} \mathrm{C}$ for use. RNA preparation 
and qRT-PCR analysis was performed according to our previous description [25]. qRT-PCR was repeated three times with different batches of treated plants and one of the representative data was shown. Gene expression values are normalized relative to the internal control AcEF1 $\alpha$. Values are the means \pm standard deviation (SD) $(n=3)$. The probe sets for real-time PCR and the corresponding primer pairs used for the analysis are listed in Table S1.

\subsection{Salt-Stress Assay for Isolated Salt Resistance Genes}

The candidate genes were retransformed into yeast INVSc1 cells and challenged with high concentrations of $\mathrm{NaCl}$ to evaluate their performance. Yeast cells containing pYES EV (control) or pYES52- Acgenes were grown in SC-U medium with shaking (200 rpm) at $28{ }^{\circ} \mathrm{C}$ for $24 \mathrm{~h}$ and their $\mathrm{OD}_{600}$ were diluted with SC-U to five different levels: $1,10^{-1}, 10^{-2}, 10^{-3}, 10^{-4}$ gradually. Two $\mu \mathrm{L}$ of each culture was spotted onto SC-U plates plus $2 \mathrm{M} \mathrm{NaCl}$. The plates were incubated at $28^{\circ} \mathrm{C}$ for 4 days and then photographed.

Supplementary Materials: Supplementary materials can be found at www.mdpi.com/1422-0067/18/11/2444/s1.

Acknowledgments: We thank Steve Daubert at University of California, Davis for critical reading of the manuscript. This study is financially supported by grants from the Thirteenth Five-Year Plan Project of Science and Technology Support, China (2016YFD0300704, 2017YFD0201802) and the International Cooperation Program in Jilin Province, China (20160414028GH).

Author Contributions: Gang Yu, Hao Zhang and Hongyu Pan designed the experiments; Gang Yu, Jingtao Li, Xinhua Sun, Yanzhi Liu and Xueliang Wang performed most of the experiments; all authors examined the data and G.Y. wrote the manuscript.

Conflicts of Interest: The authors declare no conflicts of interest.

\section{References}

1. Uga, Y.; Sugimoto, K.; Ogawa, S.; Rane, J.; Ishitani, M.; Hara, N.; Kitomi, Y.; Inukai, Y.; Ono, K.; Kanno, N.; et al. Control of root system architecture by DEEPER ROOTING 1 increases rice yield under drought conditions. Nat. Genet. 2013, 45, 1097-1102. [CrossRef] [PubMed]

2. Hasegawa, P.M.; Bressan, R.A.; Zhu, J.-K.; Bohnert, H.J. Plant Cellular and Molecular Responses to High Salinity. Annu. Rev. Plant Physiol. Plant Mol. Biol. 2000, 51, 463-499. [CrossRef] [PubMed]

3. Mishra, A.; Tanna, B. Halophytes: Potential Resources for Salt Stress Tolerance Genes and Promoters. Front. Plant Sci. 2017, 8. [CrossRef] [PubMed]

4. Gupta, B.; Huang, B. Mechanism of Salinity Tolerance in Plants: Physiological, Biochemical, and Molecular Characterization. Int. J. Genom. 2014, 2014, 701596. [CrossRef] [PubMed]

5. Jorge, T.F.; Duro, N.; da Costa, M.; Florian, A.; Ramalho, J.C.; Ribeiro-Barros, A.I.; Fernie, A.R.; António, C. GC-TOF-MS analysis reveals salt stress-responsive primary metabolites in Casuarina glauca tissues. Metabolomics 2017, 13, 95. [CrossRef]

6. Scotti-Campos, P.; Duro, N.; Costa, M.D.; Pais, I.P.; Rodrigues, A.P.; Batista-Santos, P.; Semedo, J.N.; Leitão, A.E.; Lidon, F.C.; Pawlowski, K.; et al. Antioxidative ability and membrane integrity in salt-induced responses of Casuarina glauca Sieber ex Spreng. in symbiosis with $\mathrm{N}_{2}$-fixing Frankia Thr or supplemented with mineral nitrogen. J. Plant Physiol. 2016, 196-197, 60-69. [CrossRef] [PubMed]

7. Duro, N.; Batista-Santos, P.; da Costa, M.; Maia, R.; Castro, I.V.; Ramos, M.; Ramalho, J.C.; Pawlowski, K.; Máguas, C.; Ribeiro-Barros, A. The impact of salinity on the symbiosis between Casuarina glauca Sieb. ex Spreng. and $\mathrm{N}_{2}$-fixing Frankia bacteria based on the analysis of Nitrogen and Carbon metabolism. Plant Soil 2016, 398, 327-337. [CrossRef]

8. Batista-Santos, P.; Duro, N.; Rodrigues, A.P.; Semedo, J.N.; Alves, P.; da Costa, M.; Graça, I.; Pais, I.P.; Scotti-Campos, P.; Lidon, F.C.; et al. Is salt stress tolerance in Casuarina glauca Sieb. ex Spreng. associated with its nitrogen-fixing root-nodule symbiosis? An analysis at the photosynthetic level. Plant Physiol. Biochem. 2015, 96, 97-109. [CrossRef] [PubMed]

9. Wang, J.; Meng, Y.; Li, B.; Ma, X.; Lai, Y.; Si, E.; Yang, K.E.; Xu, X.; Shang, X.; Wang, H.; et al. Physiological and proteomic analyses of salt stress response in the halophyte Halogeton glomeratus. Plant Cell Environ. 2015, 38, 655-669. [CrossRef] [PubMed] 
10. Shabala, S. Learning from halophytes: Physiological basis and strategies to improve abiotic stress tolerance in crops. Ann. Bot. 2013, 112, 1209-1221. [CrossRef] [PubMed]

11. Wu, H.-J.; Zhang, Z.; Wang, J.-Y.; Oh, D.-H.; Dassanayake, M.; Liu, B.; Huang, Q.; Sun, H.-X.; Xia, R.; Wu, Y.; et al. Insights into salt tolerance from the genome of Thellungiella salsuginea. Proc. Natl. Acad. Sci. USA 2012, 109, 12219-12224. [CrossRef] [PubMed]

12. Xu, J.; Yin, H.; Yang, L.; Xie, Z.; Liu, X. Differential salt tolerance in seedlings derived from dimorphic seeds of Atriplex centralasiatica: From physiology to molecular analysis. Planta 2011, 233, 859-871. [CrossRef] [PubMed]

13. Qi, X.; Li, M.-W.; Xie, M.; Liu, X.; Ni, M.; Shao, G.; Song, C.; Kay-Yuen Yim, A.; Tao, Y.; Wong, F.-L.; et al. Identification of a novel salt tolerance gene in wild soybean by whole-genome sequencing. Nat. Commun. 2014, 5. [CrossRef] [PubMed]

14. Benzarti, M.; Ben Rejeb, K.; Debez, A.; Abdelly, C. Environmental and economical opportunities for the valorisation of the genus Atriplex: New insights. In Crop Improvement: New Approaches and Modern Techniques; Hakeem, R.K., Ahmad, P., Ozturk, M., Eds.; Springer: Boston, MA, USA, 2013.

15. Buckholz, R.G.; Gleeson, M.A.G. Yeast systems for the commercial production of heterologous proteins. Nat. Biotechnol. 1991, 9, 1067-1072. [CrossRef]

16. Nakahara, Y.; Sawabe, S.; Kainuma, K.; Katsuhara, M.; Shibasaka, M.; Suzuki, M.; Yamamoto, K.; Oguri, S.; Sakamoto, H. Yeast functional screen to identify genes conferring salt stress tolerance in Salicornia europaea. Front. Plant Sci. 2015, 6. [CrossRef] [PubMed]

17. Kappachery, S.; Yu, J.W.; Baniekal-Hiremath, G.; Park, S.W. Rapid identification of potential drought tolerance genes from Solanum tuberosum by using a yeast functional screening method. Comptes Rendus Biol. 2013, 336, 530-545. [CrossRef] [PubMed]

18. Gangadhar, B.; Yu, J.; Sajeesh, K.; Park, S. A systematic exploration of high-temperature stress-responsive genes in potato using large-scale yeast functional screening. Mol. Genet. Genom. 2013, 289, 185-201. [CrossRef] [PubMed]

19. Eswaran, N.; Parameswaran, S.; Sathram, B.; Anantharaman, B.; Kumar, G.R.; Tangirala, S. Yeast functional screen to identify genetic determinants capable of conferring abiotic stress tolerance in Jatropha curcas. BMC Biotechnol. 2010, 10, 23. [CrossRef] [PubMed]

20. Li, J.; Sun, X.; Yu, G.; Jia, C.; Liu, J.; Pan, H. Generation and analysis of expressed sequence tags (ESTs) from halophyte Atriplex canescens to explore salt-responsive related genes. Int. J. Mol. Sci. 2014, 15, 11172-11189. [CrossRef] [PubMed]

21. Zhu, J.-K. Plant salt tolerance. Trends Plant Sci. 2001, 6, 66-71. [CrossRef]

22. Sun, X.-H.; Yu, G.; Li, J.-T.; Jia, P.; Zhang, J.-C.; Jia, C.-G.; Zhang, Y.-H.; Pan, H.-Y. A heavy metal-associated protein (AcHMA1) from the halophyte, Atriplex canescens (Pursh) Nutt., confers tolerance to iron and other abiotic stresses when expressed in Saccharomyces cerevisiae. Int. J. Mol. Sci. 2014, 15, 14891-14906. [CrossRef] [PubMed]

23. Yu, G.; Li, J.; Sun, X.; Zhang, X.; Liu, J.; Pan, H. Overexpression of AcNIP5;1, a novel nodulin-like intrinsic protein from halophyte Atriplex canescens, enhances sensitivity to salinity and improves drought tolerance in Arabidopsis. Plant Mol. Biol. Rep. 2015, 33, 1864-1875. [CrossRef]

24. Li, J.; Yu, G.; Sun, X.; Liu, Y.; Liu, J.; Zhang, X.; Jia, C.; Pan, H. AcPIP2, a plasma membrane intrinsic protein from halophyte Atriplex canescens, enhances plant growth rate and abiotic stress tolerance when overexpressed in Arabidopsis thaliana. Plant Cell Rep. 2015, 34, 1401-1415. [CrossRef] [PubMed]

25. Li, J.; Yu, G.; Sun, X.; Zhang, X.; Liu, J.; Pan, H. AcEBP1, an ErbB3-Binding Protein (EBP1) from halophyte Atriplex canescens, negatively regulates cell growth and stress responses in Arabidopsis. Plant Sci. 2016, 248, 64-74. [CrossRef] [PubMed]

26. Pan, Y.-Q.; Guo, H.; Wang, S.-M.; Zhao, B.; Zhang, J.-L.; Ma, Q.; Yin, H.-J.; Bao, A.-K. The photosynthesis, $\mathrm{Na}^{+} / \mathrm{K}^{+}$homeostasis and osmotic adjustment of Atriplex canescens in response to salinity. Front. Plant Sci. 2016, 7. [CrossRef] [PubMed]

27. Liu, X.-D.; Xie, L.; Wei, Y.; Zhou, X.; Jia, B.; Liu, J.; Zhang, S. Abiotic Stress Resistance, a Novel Moonlighting Function of Ribosomal Protein RPL44 in the Halophilic Fungus Aspergillus glaucus. Appl. Environ. Microbiol. 2014, 80, 4294-4300. [CrossRef] [PubMed]

28. Agarie, S.; Shimoda, T.; Shimizu, Y.; Baumann, K.; Sunagawa, H.; Kondo, A.; Ueno, O.; Nakahara, T.; Nose, A.; Cushman, J.C. Salt tolerance, salt accumulation, and ionic homeostasis in an epidermal bladder-cell-less 
mutant of the common ice plant Mesembryanthemum crystallinum. J. Exp. Bot. 2007, 58, 1957-1967. [CrossRef] [PubMed]

29. Casas, A.M.; Nelson, D.E.; Raghothama, K.G.; D’Urzo, M.P.; Singh, N.K.; Bressan, R.A.; Hasegawa, P.M. Expression of Osmotin-Like Genes in the Halophyte Atriplex nummularia L. Plant Physiol. 1992, 99, 329-337. [CrossRef] [PubMed]

30. Ma, J.F.; Yamaji, N. A cooperative system of silicon transport in plants. Trends Plant Sci. 2015, 20, 435-442. [CrossRef] [PubMed]

31. Martinez-Ballesta, M.D.C.; Carvajal, M. New challenges in plant aquaporin biotechnology. Plant Sci. 2014, 217-218, 71-77. [CrossRef] [PubMed]

32. Lecourieux, F.; Kappel, C.; Lecourieux, D.; Serrano, A.; Torres, E.; Arce-Johnson, P.; Delrot, S. An update on sugar transport and signalling in grapevine. J. Exp. Bot. 2014, 65, 821-832. [CrossRef] [PubMed]

33. Sugihara, K.; Hanagata, N.; Dubinsky, Z.; Baba, S.; Karube, I. Molecular Characterization of cDNA Encoding Oxygen Evolving Enhancer Protein 1 Increased by Salt Treatment in the Mangrove Bruguiera gymnorrhiza. Plant Cell Physiol. 2000, 41, 1279-1285. [CrossRef] [PubMed]

34. Sun, X.; Jia, P.; Zhang, J.; Pan, H. Cloning and characterization of a salt responsive gene AcPsbQ1 from Atriplex canescens. Hereditas (Beijing) 2015, 37, 84-90.

35. Zhou, W.; Jia, C.-G.; Wu, X.; Hu, R.-X.; Yu, G.; Zhang, X.-H.; Liu, J.-L.; Pan, H.-Y. ZmDBF3, a Novel Transcription Factor from Maize (Zea mays L.), Is Involved in Multiple Abiotic Stress Tolerance. Plant Mol. Biol. Rep. 2015, 34, 353-364. [CrossRef]

36. Li, X.; Zhang, D.; Li, H.; Wang, Y.; Zhang, Y.; Wood, A.J. EsDREB2B, a novel truncated DREB2-type transcription factor in the desert legume Eremosparton songoricum, enhances tolerance to multiple abiotic stresses in yeast and transgenic tobacco. BMC Plant Biol. 2014, 14, 1-16. [CrossRef] [PubMed]

37. Li, H.; Zhang, D.; Li, X.; Guan, K.; Yang, H. Novel DREB A-5 subgroup transcription factors from desert moss (Syntrichia caninervis) confers multiple abiotic stress tolerance to yeast. J. Plant Physiol. 2016, 194, 45-53. [CrossRef] [PubMed]

38. Wang, W.; Vinocur, B.; Shoseyov, O.; Altman, A. Role of plant heat-shock proteins and molecular chaperones in the abiotic stress response. Trends Plant Sci. 2004, 9, 244-252. [CrossRef] [PubMed]

39. Wang, W.; Vinocur, B.; Altman, A. Plant responses to drought, salinity and extreme temperatures: Towards genetic engineering for stress tolerance. Planta 2003, 218, 1-14. [CrossRef] [PubMed]

40. Romanos, M.A.; Scorer, C.A.; Clare, J.J. Foreign gene expression in yeast: A review. Yeast 1992, 8, $423-488$. [CrossRef] [PubMed]

41. Huang, X.; Madan, A. CAP3: A DNA Sequence Assembly Program. Genome Res. 1999, 9, 868-877. [CrossRef] [PubMed]

(C) 2017 by the authors. Licensee MDPI, Basel, Switzerland. This article is an open access article distributed under the terms and conditions of the Creative Commons Attribution (CC BY) license (http://creativecommons.org/licenses/by/4.0/). 